\title{
PENGARUH SISTEM MANAJEMEN MUTU ISO 9001:2008 DAN PARTISIPASI PENYUSUNAN ANGGARAN TERHADAP KINERJA MANAJERIAL
}

\author{
Umiyati \\ UIN Syarif Hidayatullah Jakarta \\ umiyati@uinjkt.ac.id
}

\begin{abstract}
.
The objective of this research is to analyze and to prove empirical evidence regarding with the influence of the application of quality management system of ISO 9001:2008 and the budget participation towards the improvement of managerial performance in State Islamic University (UIN) Syarif Hidayatullah Jakarta. The technique that used in this research is multiple linier regression. The result of this research proves the hypothesis build up before this research, that there significant influence between quality management system of ISO 9001:2008 and the budget participation towards the managerial performance, both through parameter test and simultaneous test. It shows that the application of quality system management ISO 9001:2008 and the budget participation done by State Islamic University (UIN) Syarif Hidayatullah Jakarta, influence the improvement of its managerial performance
\end{abstract}

Keywords: quality management system; budget participation; managerial performance

\begin{abstract}
Abstrak.
Tujuan penelitian ini adalah untuk menganalisis dan memperoleh bukti empiris tentang pengaruh penerapan sistem manajemen mutu ISO 9001:2008 dan partisipasi penyusunan anggaran terhadap peningkatan kinerja manajerial pada Universitas Islam Negeri (UIN) Syarif Hidayatullah Jakarta. Teknik analisis yang dipergunakan ialah regresi linier berganda. Hasil penelitian menunjukan bukti yang signifikan terhadap hipotesis penelitian yang dibangun, yaitu terdapat pengaruh yang signifikan antara sistem manajemen mutu ISO 9001:2008 dan partisipasi penyusunan anggaran terhadap kinerja manajerial, baik pengujian yang dilakukan secara parameter maupun simultan. Hal ini menunjukan bahwa penerapan sistem manajemen mutu ISO 9001:2008 dan partisipasi penyusunan anggaran yang telah dilakukan di UIN Syarif Hidayatullah Jakarta, memiliki pengaruh bagi peningkatan kinerja manajerial UIN Syarif Hidayatullah Jakarta.
\end{abstract}

Kata kunci: sistem manajemen mutu; partisipasi anggaran; kinerja manajerial

Diterima: 5 Februari 2015; Direvisi: 15 Maret 2015; Disetujui: 22 Maret 2015 


\section{PENDAHULUAN}

Dalam perkembangan teknologi dan globalisasi saat ini, yang paling diperhatikan oleh sebuah organisasi pendidikan adalah berupa keinginan pelanggan yang semakin beragam dan kritis terhadap mutu lulusan maupun pelayanan yang diberikan. Peningkatan kompetisi, pilihan dan tuntutan pelanggan pendidikan mempengaruhi pendidikan saat ini. Pendidikan perlu mendapat pengaturan dan standarisasi untuk memenangkan kompetisi dan peningkatan secara berkelanjutan. Oleh karena itu organisasi pendidikan harus mengembangkan kreativitas, inovasi dan modernisasi yang disesuaikan dengan kebutuhan saat ini.

Untuk dapat diperoleh dan mempertahankan kelangsung hidup sebuah organisasi pendidikan dalam menghadapi persaingan bebas dan kompetitif tersebut, diperlukan suatu komitmen organisasi yang mengarah kepada kepuasan pelanggan (customers), dimana mutu merupakan faktor utama yang mempengaruhi pilihan konsumen untuk melihat kualitas pelayanan dan kualitas para lulusannya, mutu juga merupakan suatu kekuatan yang dapat meningkatkan kinerja manajerial pada sebuah lembaga pendidikan.

Pengelolaan mutu dapat dijalankan melalui Total Quality Manajemen (TQM), yang sesungguhnya merupakan payung dari segala sistem manajemen mutu yang ada, karena TQM mencakup segala aspek kegiatan organisasi pendidikan yang harus dikelola dengan benar, Supaya mutu hasil kerjanya dapat memuaskan pemilik dari organisasi tersebut. ISO 9001:2008 merupakan salah satu manajemen mutu yang berprinsip pada TQM. Sistem ini sangat populer karena penerapannya mendetail dan sistematis. Sistem ISO merupakan sarana atau alat untuk mencapai tujuan mutu yang diharapkan dan mampu menjawab tantangan globalisasi saat ini. Selain itu, didalamya terdapat keharusan pengawasan mutu internal secara periodik (Internal Quality Audit). Pada saat ini ISO 9001:2008 menjadi pilihan utama bagi lembaga pendidikan untuk menerapkan sistem manajemen mutu secara konsisten dan sistematis untuk tercapainya efektivitas dan efesiensi organisasi (Wiryodiningrat, 1997). 
Dalam lingkungan perguruan tinggi, yang dimaksud dengan penjaminan mutu atau kualitas adalah pelayanan jasa yang diberikan oleh perguruan tinggi terhadap stakeholder, yang terdiri dari mahasiswa, alumni, pengguna lulusan/dunia industri dan orangtua mahasiswa. Stakeholder akan menyebutkan aspek apa saja yang dinilai dalam menentukan mutu perguruan tinggi tersebut, misalnya aspek yang berhubungan dengan materi perkuliahan dan kurikulum yang link and match dengan dunia industry, proses perkuliahan yang sesuai dengan ketentuan berlaku, kompetensi dosen yang sesuai dan sarana dan prasarana yang menunjang jalannya proses pembelajaran.

Sebagai sebuah perguruan tinggi negeri yang menuju kepada sebuah universitas kelas dunia (world class university), Universitas Islam Negeri Syarif Hidayatullah Jakarta telah memiliki visi dan misi untuk mengedepankan kualitas baik itu dari lulusannya maupun dari segi penyelenggaraan pendidikan serta membangun good university governance. Dengan demikian UIN Syarif Hidayatullah Jakarta berusaha keras untuk membangun dan menerapkan sistem manajemen mutu ISO 9001:2008 untuk diperolehnya sertifikat ISO 9001: 2008. Sertifikat ISO 9001:2008 yang diperolehnya tersebut menunjukan UIN Syarif Hidayatullah Jakarta telah mempunyai bukti nyata yang diakui secara nasional maupun internasional bahwa UIN Syarif Hidayatullah Jakarta benar-benar telah menerapkan manajemen mutu dalam proses operasional kegiatan belajar dan mengajar.

Dalam usaha mencapai kinerja manajerial yang optimal, organisasi pendidikan seperti UIN Syarif Hidayatullah Jakarta seharusnya tidak hanya terpusat pada sistem manajamen mutu saja, namum sebaiknya dari sisi financial dapat dijadikan perhatian yang sangat penting terutama pada saat penyusunan anggaran. UIN Syarif Hidayatullah Jakarta merupakan salah satu instansi pemerintah yang berada dibawah Dirjen Pendidikan Islam telah menerapkan pengelolaan keuangan Badan Layanan Umum (BLU) sejak tanggal 26 Februari 2008, dengan demikian UIN Syarif Hidayatullah Jakarta berkewajiban untuk menyusun Rencana Bisnis Anggaran (RBA) yang merupakan refleksi program dan kegiatan dari kementerian negara/lembaga/pemerintah daerah. 
Penyusunan Rencana Bisnis Anggaran (RBA) yang diterapkan di UIN Syarif Hidyatullah Jakarta menggunakan sistem desentralisasi dan perencanaanya melibatkan seluruh unsur (bottom up). Anggaran yang disusun berbasis kinerja dan prinsip $3 \mathrm{E}$ (ekonomis, efesiensi dan efektif) (Umiyati, 2013).

UIN Syarif Hidayatullah Jakarta sebelum diterapkannya pengelolaan keuangan Badan Layanan Umum (BLU) masih menggunakan metode yang tradisional atau item line budget. Cara penyusunan anggaran ini tidak didasarkan pada analisa rangkaian kegiatan yang harus dihubungkan dengan tujuan yang telah ditentukan, namun lebih dititikberatkan pada kebutuhan untuk belanja/pengeluaran. Sistem pertanggungjawabannya tidak diperiksa dan diteliti apakah dana tersebut telah digunakan secara efektif dan efisien atau tidak. Tolok ukur keberhasilan hanya ditunjukkan dengan adanya keseimbangan anggaran antara pendapatan dan belanja, namun jika anggaran tersebut defisit atau surplus berarti pelaksanaan anggaran tersebut gagal (Umiyati, 2013).

Namun setelah UIN Syarif Hidayatullah Jakarta telah menerapkan pengelolaan keuangan Badan Layanan Umum (BLU) yang penganggarannya berbasis kinerja, maka penganggarannya disusun berdasarkan pada hasil output. Sistem ini menitikberatkan pada segi penatalaksanaan sehingga selain efisiensi penggunaan dana juga hasil kerjanya diperiksa. Jadi, tolok ukur keberhasilan sistem anggaran ini adalah performance atau prestasi dari tujuan atau hasil anggaran dengan menggunakan dana secara efisien.

Anggaran dalam proses pembuatannya terdapat dua sistem yaitu, top down dan bottom up. Sebelum adanya perubahan sistem pembuatan anggaran yang mengharuskan adanya akuntabilitas dalam proses pembuatan dan pelaporan, instansi pemerintah masih menggunakan sistem top down. Dimana rencana dan jumlah anggaran yang telah ditetapkan oleh atasan atau pemegang kuasa anggaran, bawahan atau pelaksana anggaran hanya melakukan apa yang telah disusun. Penerapan sistem ini dapat mengakibatkan kinerja bawahan atau pelaksana anggaran menjadi tidak efektif, karena atasan terlalu menuntut 
namun sumber daya pelaksanaan anggaran tidak mencukupi. Selain itu kuasa pembuat anggaran terkadang kurang mengetahui potensi dan hambatan yang dimiliki oleh bawahan atau pelaksana anggaran, sehingga target anggaran yang diberikan melebihi kemampuan pelaksana anggaran (Umiyati,2013).

Proses pembuatan anggaran dengan sistem top down sangat berbeda dengan sistem bottom up. Anggaran dengan sistem bottom up merupakan proses pembuatan anggaran yang dilakukan secara bersama-sama antara pemegang kuasa dan pelaksanaan anggaran. Hal ini dapat dilakukan sebagai sarana yang efektif dan efesien dalam mencapai tujuan. Dalam proses penyusunan anggaran, sebaiknya semua tingkatan manajemen ikut berpartisipasi (terlibat). Partisipasi dalam penyusunan anggaran yang melibatkan sumber daya manusia mempunyai pengaruh yang besar dalam penentuan besarnya anggaran dalam institusi atau organisasi (Govindrajan, 2005).

Banyak penelitian bidang akuntansi manajemen yang menaruh perhatian pada masalah partisipasi anggaran, hal ini karena anggaran partisipatif dinilai mempunyai konsekuensi terhadap sikap dan perilaku anggota organisasi (Murray, 1990 dalam Sardjito 2007 ). Pengaruh partisipasi anggaran terhadap kinerja manajerial merupakan tema yang menarik dalam pendidikan akuntansi manajemen. Menurut Lukka (1988) dan Brownell (1982) dalam Sumarno (2005) ada dua alasan yaitu (a) partisipasi dinilai sebagai pendekatan manajerial yang dapat meningkatkan kinerja dan (b) berbagai penelitian yang menguji antara partisipasi anggaran terhadap kinerja manajerial hasilnya saling bertentangan. Sehingga para peneliti menyimpulkan bahwa tidak ada hubungan langsung antara partisipasi anggaran dan kinerja manajerial (Gul.et.al, 1995 dalam Nor, 2009).

\section{Sistem Manajemen Mutu ISO 9001:2008}

Sistem Manajemen adalah suatu kegiatan terkoordinasi untuk mengarahkan dan mengendalikan organisasi dalam hubungannya dengan mutu. Sistem manajemen mutu dapat dijadikan alat strategis untuk 
mengembangkan kinerja proses dan sumber daya dalam melakukan peningkatan terus menerus, memberikan pelayanan prima demi kepuasan pengguna untuk mempersiapkan diri menghadapi persaingan international dan mendapatkan pengakuan international terhadap proses yang dilakukan. Tuntutan penjamin mutu kemudian melahirkan suatu standar yang lebih berorientasi kepada sistem dan proses yaitu Standar Manajemen Mutu (Bambangkesit, 2009)

ISO berasal dari bahasa Yunani yang berarti sama. ISO 9001 merupakan standar internasional yang mengatur tentang sistem manajemen mutu (Quality Manajemen System). Dalam sistem manajemen mutu ISO 9001 terdapat standar operating prosedur (SOP), intruksi kerja (work instruction), tujuan dan sasaran mutu (quality objective) dan juga program mutu (quality program) (http:WW.ISO.Org/about/htm). ISO 9001:2008 adalah sistem manajemen mutu ISO 9001 hasil revisi tahun 2008 yang menetapkan persyaratan-persyaratan dan rekomendasi untuk desain dan penilaian dari suatu sistem manajemen kualitas yang bertujuan untuk menjamin bahwa organisasi akan memberikan produk (barang/jasa) yang memenuhi persyaratan yang ditetapkan (Gaspersz, 2002).

Struktur ISO 9001:2008 yang dijadikan pedoman dalam sisitem manajemen mutu pada suatu organisasi terdiri dari 8 klausul, diantaranya: (1). Ruang Lingkup; (2). Referensi Standar; (3). Istilah dan Definisi; (4). Sistem Manajemen Mutu; (5). Tanggungjawab Manajemen; (6). Manajemen Sumber Daya; (7). Realisasi Produk; (8). Pengukuran, Analisa dan Perbaikan (Rahmawaty, 2009).

Di dalam ISO 9001:2008 yang menjadi persyaratan hanyalah klausul 4: Sistem Manajemen Mutu, klausul 5: Tanggungjawab Manajemen, klausul 6: Manajemen Sumber Daya, klausul 7: Realisasi Produk, dan klausul l 8: Pengukuran, Analisa dan Perbaikan. Jadi suatu organisasi yang ingin menerapkan ISO 9000 atau ingin mendapatkan sertifikasi ISO 9001 cukup dengan menerapkan kelima pasal tersebut (Rahmawaty, 2009). 
Jika dikelompokkan secara pendekatan proses maka klausul 5: Tanggungjawab Manajemen dan klausul: Manajemen Sumber Daya merupakan bagian dari Proses Perencanaan (plan), klausul 7: Realisasi Produk merupakan bagian dari Proses Melakukan (do), dan klausul 8: Pengukuran, Analisa dan Perbaikan merupakan bagian dari Proses Pemeriksaan (check) dan Proses Tindakan (Act). Integrasi proses-proses Plan-Do-Check-Act (PDCA) tersebut secara sistematik akan menghasilkan suatu pendekatan Sistem Manajemen Mutu (klausul 4) ke arah perbaikan kinerja secara berkesinambungan (Setyawan,Wawan, 2014). Standar ISO 9001 :2008 dapat diterapkan oleh perguruan tinggi sebagai kerangka sistem manajemen mutu karena standar tersebut bersifat generik dan dapat diterapkan pada semua organisasi tanpa dibatasi oleh tipe, ukuran dan produk yang dihasilkan.

Upaya penerapan ISO 9001:2008 di perguruan tinggi dapat dilihat sebagai sebuah langkah untuk mewujudkan dan memberikan tata kelola yang baik, meraih praktik pendidikan yang prima, meningkatkan kepuasan pelanggan dan memberikan respon yang lebih baik pada kebutuhan industri (Othman \& Abdullah, 2007). Van den Berghe (1997) menyebutkan beberapa motif utama yang dimiliki oleh perguruan tinggi untuk menerapkan ISO 9001 adalah sebagai langkah promosi untuk memberikan gambaran bahwa organisasi memiliki mutu tinggi, visibilitas yang tinggi dan kredibilitas, respon pada faktor eksternal dan untuk mengembangkan sistem manajmen mutu secara keseluruhan, serta untuk mendorong peningkatan secara spesifik pada beberapa kegiatan organisasi.

\section{Partisipasi Penyusunan Anggaran}

Anggaran adalah pernyataan terkuantifikasi dan tertulis dari rencana manajemen (Carter, 2009). Anggaran merupakan suatu pernyataan formal yang dibuat oleh manajamen tentang rencana-rencana yang akan dilakukan pada masa yang akan datang dalam suatu periode tertentu, dimana rencana tersebut adalah sebagai pedoman dalam pelaksanaan kegiatan selama periode tertentu (Ahmad, 2005). 
Penganganggaran merupakan proses penerjemahan dari aktivitas ke dalam rencana keuangan. Dalam sebuah organisasi besar, penganggaran boleh jadi merupakan proses yang terus menerus. Bagi organisasi yang besar dan telah matang (mature) dengan tingkat operasional yang relative stabil dalam jangka panjang, anggaran merupakan dokumen formal yang terinci. Untuk perlu waktu yang lama dalam menyiapkan suatu anggaran agar tersedia tepat diperiode tahun berikutnya dan disetujui semua pihak (Arifah, 2009).

Partisipasi anggaran memungkinkan para manajer tingkat bawah untuk turut serta dalam pembuatan anggaran. Biasanya tujuan umum dikomunikasikan ke manajer, yang membantu mengembangkan anggaran yang akan memenuhi tujuan-tujuan ini. Partisipasi anggaran mengkomunikasikan rasa bertanggungjawab pada para manajer tingkat bawah dan mendorong kreativitas (Hansen dan Mowen, 2009).

Anggaran dapat dijadikan sebagai alat penilaian kinerja, maksudnya adalah kinerja dapat dinilai berdasarkan pencapaian target anggaran dan efesiensi pelaksanaan anggaran (Mardiasmo, 2002). Proses Penyusunan anggaran merupakan kegiatan yang penting dan melibatkan, mengkomunikasikan, memotivasi dan mengevaluasi berbagai alternatif dan tujuan anggaran, dimana anggaran senantiasa digunakan sebagai tolak ukur kinerja manajer.

Dengan demikian, penyusunan anggaran secara partisipasi adalah melibatkan berbagai individu atau manajer tingkat menengah sampai dengan manajer tingkat bawah dalam sebuah organisasi untuk merumuskan semua atau sebagian dari anggaran. Dengan menyusun anggaran secara partisipasi, diharapkan dapat meningkatkan kinerja setiap individu sesuai dengan target yang telah ditetapkan. Hal ini didasarkan pada pemikiran bahwa ketika suatu tujuan atau standar yang direncanakan secara partisipatif disetujui, maka setiap individu akan melaksanakan standar yang ditetapkan dan manajer juga memiliki rasa tanggung jawab pribadi untuk mencapainya, karena mereka ikut serta terlibat dalam penyusunan. 


\section{Kinerja Manajerial}

Menurut Mahoney et.al., (1963) dalam Yuniarti, et.al., (2007) menyatakan bahwa kinerja (performance) adalah sebagai berikut:

"Kinerja adalah hasil kerja yang dapat dicapai oleh seorang atau sekelompok orang dalam suatu organisasi, sesuai dengan wewenang dan tanggung jawab masing-masing, dalam rangka mencapai tujuan organisasi"

Kinerja merupakan salah satu faktor penting yang digunakan dalam mengukur efektivitas dan efesiensi suatu organisasi. Pengukuran kinerja adalah sistem yang bertujuan untuk membantu manajer dalam menilai pencapaian strategi melalui alat ukur dengan berdasarkan perspektif keuangan dan non keuangan Sistem pengukuran kinerja dapat dijadikan sebagai pengendalian organisasi karena pengukuran kinerja diperkuat dengan menetapkan reward dan punishmen system (Arifah, 2009). Mahoney, et al., (1963) dalam Sumarno, (2005) bahwa kinerja para individu dalam kegiatan manajerial diukur meliputi delapan bidang aktivitas manajemen, yaitu perencanaan, investigasi, pengkoordinasian, evaluasi, pengawasan (Supervisi), pengaturan staf, negosiasi, perwakilan atau respresentatif serta pengukuran kinerja secara menyeluruh. Kinerja sebagai hasil kerja yang dapat dicapai oleh seseorang atau sekelompok orang dalam suatu organisasi sesuai dengan wewenang dan tanggung jawab masing-masing dalam upaya mencapai tujuan organisasi yang bersangkutan secara legal, tidak melanggar hukum dan sesuai dengan moral dan etika (Prawirosentono, 1999).

\section{Pengembangan Hipotesis}

Dalam era globalisasi, tantangan bagi suatu lembaga baik pemerintah maupun swasta adalah kemampuan untuk menjamin kepuasan pelanggan atau mitra kerja. Begitu pula pada lembaga penyelenggaraan pendidikan, dalam pelaksanaannya harus melakukan penjaminan terhadap proses pendidikan yang dilaksanakan dengan bertujuan pada peningkatan kepuasan pelanggan. Salah satu upaya untuk melakukan penjaminan mutu proses pendidikan yaitu dengan menerapkan sistem manajemen mutu ISO 9001:2008. Dengan menerapkan sistem manajemen mutu ISO 9001:2008 ini diharapkan terjadi 
pengembangan berkelanjutan (continual improvement) terhadap kinerja lembaga sebuah lembaga institusi penyelenggaraan pendidikan yang lebih baik dari waktu ke waktu.

Ini sejalan dengan hasil penelitian yang dilakukan oleh rahmawaty (2009) yang menunjukan bahwa terdapat pengaruh positif signifikan penerapan SMM ISO 9001:2000 terhadap kinerja organisasi dengan nilai $\mathrm{F}$ hitung sebesar 28,236 dengan signifikan 0,000, nilai $\mathrm{R}^{2}$ sebesar 0,224 yang berarti bahwa penerapan SMM ISO 9001:2008 berpengaruh terhadap kinerja organisasi. Begitu pula dengan penelitian yang dilakukan oleh lestari (2012) yang menyatakan bahwa Sistem Manajemen Mutu ISO 9001:2008 berpengaruh terhadap peningkatan kinerja UNIKA Atmajaya Jakarta.

Berdasarkan uraian diatas serta temuan-temuan penelitian yang telah dilakukan, maka penelitian ini dimaksudkan untuk menguji kembali pengaruh Sistem Manajemen Mutu ISO 9001:2008 terhadap kinerja manajerial khususnya di Universitas Islam Negeri Syarif Hidayatullah Jakarta. Bedaskan hal tersebut maka disusunlah hipotesis sebagai berikut :

$\mathrm{H}_{1}$ : $\quad$ Sistem Manajemen Mutu ISO 9001:2008 berpengaruh secara signifikan terhadap kinerja manajerial

Pengendalian merupakan tindakan yang diperlukan manajemen untuk meyakinkan dan menilai apakah tujuan, rencana, dan standar yang telah ditetapkan dapat dicapai. Penyusunan anggaran dengan melibatkan pihak atasan atau pemegang kuasa dengan bawahan atau pelaksana anggaran merupakan salah satu alat yang berfungsi sebagai alat perencanaan dan pengendalian serta dapat digunakan sebagai tolak ukur dan meningkatkan kinerja manajerial. Oleh karena itu, anggaran harus disusun pada tiap-tiap tingkatan manajemen melalui pembentukan pusa-pusat pertanggungjawaban, serta laporan anggaran dan realisasinya dari setiap pusat pertanggungjawaban untuk dapat menentukan prestasi pusat pertanggungjawaban.

Anggaran dapat dijadikan sebagai alat penilaian kinerja, maksudnya adalah kinerja dapat dinilai berdasarkan pencapaian target anggaran dan efesiensi pelaksanaan anggaran. Proses Penyusunan anggaran merupakan 
kegiatan yang penting dan melibatkan, mengkomunikasikan, memotivasi dan mengevaluasi berbagai alternatif dan tujuan anggaran, dimana anggaran senantiasa digunakan sebagai tolak ukur kinerja manajer. Berbagai penelitian telah dilakukan untuk menguji pengaruh partisipasi anggaran terhadap kinerja manajerial. Dari hasil penelitian yang telah dilakukan menunjukan adanya perbedaan antara penelitian yang satu dengan penelitian yang lainnya. Brownell (1982); Sumarno (2005); Yusfaningrum dan Ghozali (2005); Sardjito (2007); Nurcahyani (2010); Arifah (2009) dan Fitrianti (2010) hasil penelitian mereka tersebut menemukan bahwa terdapat hubungan yang positif dan signifikan antara partsipasi anggaran dengan kinerja manajerial. Sedangkan hasil penelitian (Baryan Locke, 1967 dalam Nor 2009); Milani (1975); Yuniarti (2007) menemukan bahwa terdapat hubungan yang tidak siginifikan antara partisipasi anggaran dengan kinerja manajerial.

Partisipasi dalam penyusunan anggaran lebih mengacu pada sejauh mana atasan berpartsipasi dalam penyusunan anggaran dan mempengaruhi sasaran untuk mencapai kinerja manajerial. Sasaran dapat dipandang sebagai tujuan atau tingkat kinerja yang ingin dicapai oleh individu. Berdasarakan uraian diatas serta temuan-temuan penelitian yang telah dilakukan maka penelitian ini dimaksudkan untuk menguji kembali pengaruh partisipasi penyusunan anggaran terhadap kinerja manajerial khususnya di Universitas Islam Negeri Syarif Hidayatullah Jakarta. Hipotesis dalam penelitian ini dirumusakn sebagai berikut:

$\mathrm{H}_{2}$ : Partisipasi penyusunan anggaran berpengaruh secara signifikan terhadap kinerja manajerial.

Sistem ISO merupakan sarana atau alat untuk mencapai tujuan mutu yang diharapkan dan mampu menjawab tantangan globalisasi saat ini. Pada saat ini ISO 9001 :2008 menjadi pilihan utama bagi lembaga pendidikan untuk menerapkan sistem manajemen mutu secara konsisten dan sistematis untuk tercapaianya efektivitas dan efesiensi organisasi (Wiryodiningrat,1997). Sehingga diharapkan sistem manajemen mutu ISO 900112008 mampu untuk meningkatkan kinerja manajerial suatu organisasi. 
Dalam usaha mencapai kinerja manajerial yang optimal, lembaga atau organisasi seharusnya tidak hanya terpusat pada sistem manajamen mutu saja, namum sebaiknya dari sisi financial dapat dijadikan perhatian yang sangat penting terutama pada saat penyusunan anggaran. Dalam proses penyusunan anggaran, sebaiknya semua tingkatan manajemen ikut berpartisipasi (terlibat). Partisipasi dalam penyusunan anggaran yang melibatkan sumber daya manusia mempunyai pengaruh yang besar dalam penentuan besarnya anggaran dalam institusi atau organisasi (Govindrajan, 2005).

Berdasarkan uraian diatas serta temuan-temuan penelitian yang telah dilakukan, maka penelitian ini dimaksudkan untuk menguji pengaruh sistem manajemen mutu ISO 9001:2008 dan partisipasi penyusunan anggaran terhadap kinerja manajerial, khususnya di Universitas Islam Negeri Syarif Hidayatullah Jakarta. Hipotesis dalam penelitian ini dirumuskan sebagai berikut:

$\mathrm{H}_{3}$ : Sistem manajemen mutu ISO 9001:2008 dan partisipasi penyusunan anggaran berpengaruh secara simultan dan signifikan terhadap kinerja manajerial

\section{METODE}

Metode yang digunakan dalam penelitian ini adalah dengan menggunakan metode deskriptif. Responden dalam penelitian ini adalah seluruh pimpinan, kepala bagian dan subbagian yang terlibat dalam penyusunan anggaran di Universitas Islam Negeri (UIN) Syarif Hidayatullah Jakarta serta seluruh Dosen dan karyawan yang terlibat dalam kegiatan belajar mengajar di Rektorat dan Fakultas UIN Syarif Hidayatullah Jakarta yang telah bersertifikat ISO 9001:2008 (Fakultas Tarbiyah dan Keguruan, Fakultas Ekonomi dan Bisnis dan Fakultas Sains dan Teknologi).

Dalam penelitian ini, teknik pengumpulan data adalah dengan menggunakan kuesioner, dan pengambilan sample secara purposive sampling dengan kriteria sebagai berikut :

1. Menduduki jabatan sebagai wakil rektor, dekan, wakil dekan,kepala biro, direktur pascasarjana, kepala bagian tata usaha, kepala subbagian tata 
usaha, kepala bidang perpustakaan, ketua program studi, sekertaris program studi, dan ketua lembaga struktural UIN.

2. Individu terlibat dalam proses penyusunan anggaran tahun 2012-2013

3. Telah menduduki jabatan minimal 1 (satu) tahun

4. Seluruh Dosen dan Karyawan yang telah menjalankan proses sistem manajemn mutu ISO 9001:2008 minimal 1 (satu) tahun.

Metode statistik yang digunakan untuk menguji hipotesis adalah regresi berganda (multiple regression). Pendekatan ini diadposi dari persamaan yang digunakan Govindrajan dan Gupta (1985) dalam Sumarno (2005). Analisis ini digunakan untuk menguji pengaruh satu variabel independen terhadap variabel dependen secara individual atau parameter yaitu :

a. Menguji pengaruh penerapan sistem manajemen mutu ISO 9001:2008 $\left(\mathrm{X}_{1}\right)$ terhadap kinerja manajerial (Y) (hipotesis1).

$$
\text { Persamaan }: Y=\beta_{0}+\beta_{1} X_{1}+e
$$

b. Menguji pengaruh partisipasi penyusunan anggaran $\left(\mathrm{X}_{2}\right)$ terhadap kinerja manajerial (Y) (hipotesis2).

$$
\text { Persamaan : } \mathrm{Y}=\boldsymbol{\beta}_{0}+\boldsymbol{\beta}_{2} \mathrm{X}_{2}+\mathrm{e}
$$

c. menguji pengaruh penerapan sistem manajemen mutu ISO 9001:2008 $\left(\mathrm{X}_{1}\right)$ dan partisipasi penyusunan anggaran $\left(\mathrm{X}_{2}\right)$ terhadap kinerja manajerial (Y) (hipotesis 3).

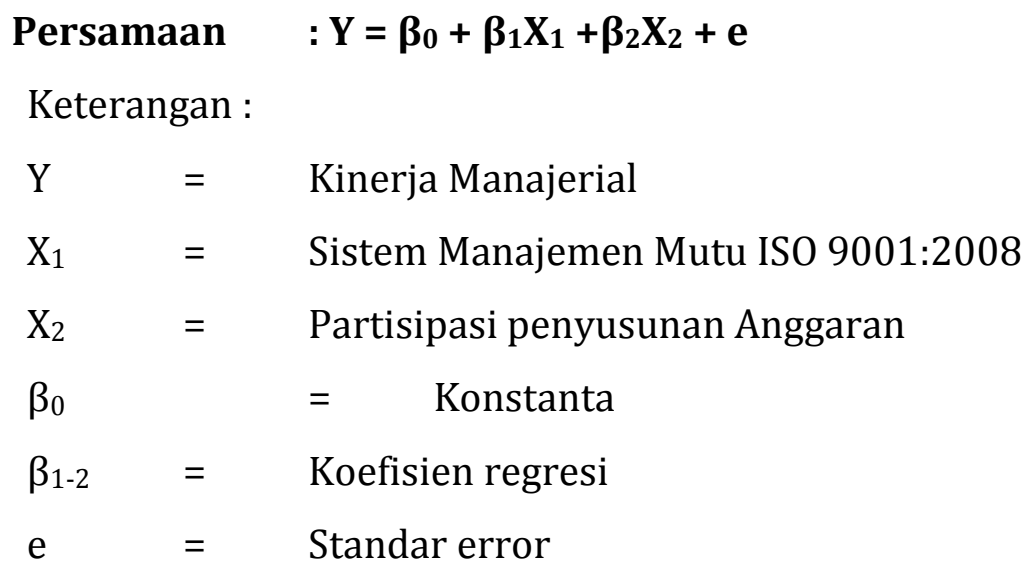

Dalam membuktikan kebenaran uji hipotesis yang diajukan secara uji statistik terhadap output yang dihasilkan dari persamaan regresi. Uji statistik yang digunakan, meliputi, Uji $\mathrm{R}^{2}$ (Koefisien Determinan) yaitu untuk mengukur 
seberapa jauh kemampuan model dalam menerangkan variasi variabel independen, Uji Signifikan Parameter Individual (Uji Statistik t) dengan tingkat siginifikan yang digunakan $5 \%$ atau 0.05 (uji dua sisi) dan Uji Signifikan Simultan (Uji Statistik F) dengan tingkat siginifikan yang digunakan $5 \%$ atau 0.05 (uji 2 sisi).

Pengujian validitas yang dilakukan pada penelitian ini menggunakan uji pearson correlation, yaitu dengan cara mengkorelasikan skor yang diperoleh pada setiap item pertanyaan dengan skor total dari masing-masing construct (Ghozali, 2005). Pengujian ini menggunakan uji dua sisi dengan tingkat siginifikan 0,05. Kriteria pengujian, Jika $r$ hitung $>r$ tabel (uji 2 sisi dengan sig.0,05) maka instrumen atau item-item pertanyaan berkorelasi siginifikan terhadap skor total (dinyatakan valid). Namun Jika $r$ hitung $<$ r tabel (uji 2 sisi dengan sig. 0,05) maka instrument atau item-item pertanyaan tidak berkorelasi siginifikan terhadap skor total (dinyatakan tidak valid). Peneliti melakukan uji reliabilitas dengan menggunakan cronbach's alpha dari masing-masing instrument dalam suatu variabel.Instrumen yang dipakai dalam variabel tersebut dapat dikatakan andal (reliabel) apabila cronbach's alpha lebih besar dari 0.60 (Ghozali 2005). Sebelum melakukan uji hipotesis dengan menggunakan analisis regresi berganda, peneliti terlebih dahulu melakukan pengujian asumsi klasik yang meliputi pengujian normalitas, multikolinearitas, heteroskodastisitas.

\section{PEMBAHASAN}

\section{Deskripsi Umum Sampel}

Responden dalam penelitian ini adalah wakil rektor, dekan, wakil dekan, kepala biro, direktur pascasarjana, kepala bagian tata usaha, kepala subbagian tata usaha, kepala bidang perpustakaan, ketua program studi, sekertaris program studi, dan ketua lembaga struktural, dosen tetap dan karyawan di UIN Syarif Hidayatullah Jakarta yang terlibat proses penyusunan anggaran tahun 2011-2012 dan telah mendudukan jabatan minimal 1 (satu) tahun, selain itu terlibat dalam penerapan sistem manajmen mutu ISO 9001:2008 minimal 1 tahun. 
Tabel 1. Data Sampel Penelitian

\begin{tabular}{clcc}
\hline No & \multicolumn{1}{c}{ Keterangan } & Jumlah & Presentase \\
\hline 1 & Jumlah kuesioner yang disebar & 100 & $100 \%$ \\
2 & Jumlah kuesioner yang tidak kembali & 10 & $10 \%$ \\
3 & Jumlah kuesioner yang tidak dapat diolah & 5 & $5 \%$ \\
4 & Jumlah kuesioner yang dapat diolah & 85 & $85 \%$ \\
\hline
\end{tabular}

Sumber: Data primer yang diolah

Kuesioner yang dikirim kepada responden sebanyak 100 buah kuesioner, dan jumlah kuesioner yang kembali sebanyak 90 kuesioner atau 90 \%. Kuesioner yang tidak kembali sebanyak 10 buah atau $10 \%$, dari 90 kuesioner yang kembali, yang dapat diolah berjumlah 85 buah atau $85 \%$, sedangkan kuesioner yang tidak dapat diolah karena tidak diisi secara lengkap oleh responden sebanyak 5 buah atau $5 \%$. Gambaran mengenai data sampel disajikan pada Tabel 1.

\section{Hasil Uji Kualitas data}

a. Hasil uji validitas terlihat bahwa instrument sistem manjemen mutu ISO 9001:2008, partisipasi penyusunan anggaran dan kinerja manajerial, menunjukan hasil dengan kriteria valid untuk semua item pertanyaan dengan nilai signifikansi lebih kecil dari 0,05, dan nilai $r$ hitung yang yang dihasilkan lebih besar dari pada nilai r tabel (uji 2 sisi dengan sig.0,05).

b. Hasil Uji Reliabilitas hasil yang reliabel untuk tiga variabel penelitian yang digunakan dalam penelitian ini.

Tabel 2. Hasil Uji Reliabilitas

\begin{tabular}{lcc}
\hline \multicolumn{1}{c}{ Variabel } & Cronbach's Alpha & Keterangan \\
\hline Kinerja Manajerial & 0,885 & Reliabel \\
Sistem Manajemen Mutu ISO & 0,932 & Reliabel \\
Partisipasi Penyusunan Anggaran & 0.890 & Reliabel \\
\hline
\end{tabular}

Sumber: data primer yang diolah 
Tabel 2 menunjukan bahwa nilai cronbach's alpha atas variabel kinerja manajerial sebesar 0,885, sistem manajemen mutu ISO 9001:2008 sebesar 0,932, dan partisipasi penyusunan anggaran sebesar 0,890. Dapat disimpulkan bahwa pernyataan dalam kuesioner ini reliabel karena mempunyai nilai cronbach's alpha lebih besar dari 0,6. Dengan demikian setiap item pernyataan yang digunakan akan mampu memperoleh data yang konsisten, yakni bila pernyataan itu diajukan kembali akan diperoleh jawaban yang relatif sama dengan sebelumnya.

\section{Hasil Uji Asumsi klasik}

Berdasarkan hasil tampilan output menunjukkan menunjukan bahwa tabulasi yang tercipta mengikuti garis diagonal. Selain itu, garis lengkung menjulur dengan sisi yang sama pada bagian kiri maupun kanan histogram. Hal ini berarti distribusi data yang terjadi adalah normal. Selain itu pada tampilan output terlihat bahwa titik-titik menyebar disekitar garis diagonal serta penyebarannya mengikuti arah garis diagonal. Berdasarkan hasil uji normalitas menggunakan grafik P-Plot maupun grafik histrogram menunjukkan terjadinya distribusi data secara normal. Sehingga dapat dikatakan bahwa model regresi ini memenuhi asumsi normalitas.

Berdasarkan output terlihat bahwa masing-masing variabel mempunyai nilai tolerance $<0,10$ dan nilai variance inflation factor (VIF) $>10$. Dimana, hasil uji multikolinieritas menunjukkan bahwa nilai VIF untuk variabel sistem manejemen mutu ISO 9001:2008 dan partisipasi penyusunan anggaran masing-masing 1.130, sedangkan nilai tolerance untuk variabel sistem manajemen mutu ISO 9001:2008 dan partisipasi penyusunan anggaran masingmasing sebesar 0,885. Dari hasil pengujian tersebut mengindikasikan bahwa tidak terjadi masalah multikolinieritas antar variabel independen dalam model regresi dan dapat digunakan dalam penelitian ini.

Berdasarkan hasil output dapat dilihat bahwa titik-titik menyebar secara acak dan tidak membentuk suatu pola tertentu, serta tersebar dengan baik di atas maupun dibawah angka 0 pada sumbu Y. Hal ini menunjukan bahwa tidak terjadi heteroskedastisitas pada model regresi, sehingga model regresi 
layak dipakai untuk memprediksi kinerja manajerial berdasarkan variabel yang mempengaruhinya yaitu sistem manajemen mutu ISO 9001:2008 dan partisipasi penyusunan anggaran.

\section{Pengujian Hipotesis}

Hipotesis pertama menguji pengaruh Sistem Manjemen Mutu ISO 9001:2008 (X $\left.\mathrm{X}_{1}\right)$ terhadap kinerja manajerial (Y). Pengujian ini dilakukan dengan menggunakan regresi linear sederhana melalui uji koefisien determinasi dan uji statistik t. Pada tabel 3 dan 4 dapat dilihat hasil uji koefisien determinasi dan uji statistik t hipotesis 1 . Hasil perhitungan nilai $\mathrm{R}$ berdasarkan tabel 3 diatas diperoleh angka korelasi 0,403 artinya hubungan variabel dependen dan independen adalah sedang. Korelasi positif menunjukan hubungan yang searah, artinya semakin meningkat variabel sistem manajemen mutu ISO 9001:2008, maka kinerja manajerial akan meningkat. Berdasarkan nilai R Square $\left(\mathrm{R}^{2}\right)$ tabel 3 menunjukan variabel sistem manajemen mutu ISO 9001:2008 dapat menjelaskan 16,2\% variabel kinerja manjerial. Sisanya 83,8\% dijelaskan oleh sebab-sebab lain diluar model.

Tabel 3. Hasil Uji Koefisien Determinasi Hipotesis 1

Model Summaryb

\begin{tabular}{lllllll}
\hline Model & $\mathrm{R}$ & R Square & Square & Estimate & $\begin{array}{l}\text { Adjusted } \\
\text { R Std. Error of }\end{array}$ & $\begin{array}{l}\text { the Durbin- } \\
\text { Watson }\end{array}$ \\
\hline 1 & $.403^{\mathrm{a}}$ & .162 & .152 & 5.227 & 1.899 \\
\hline
\end{tabular}

a. Predictors: (Constant), ISO

b. Dependent Variable: KM

Sumber : Data primer yang diolah

Tabel 4 memperoleh hasil $\mathrm{t}$ hitung sebesar 4,012 pada tingkat siginifikan 0,000 yang berarti lebih kecil dari 0,05, sehingga uji $t$ dapat simpulkan bahwa secara individual sistem manajemen mutu ISO 9001:2008 mempunyai pengaruh yang signifikan terhadap variabel kinerja manajerial. Hal ini berarti mendukung $\mathrm{H}_{1}$ yang menyatakan bahwa sistem manajemen mutu ISO 9001:2008 berpengaruh secara signifikan terhadap 
kinerja manajerial. Hasil penelitian ini konsisten dengan penelitian yang dilakukan oleh Rahmawaty (2009) dan Lestari (2012) yang menyatakan bahwa sistem manajemen mutu ISO 9001:2008 berpengaruh secara siginifikan terhadap kinerja manajerial.

\section{Tabel 4. Hasil Uji Statistik t Hipotesis 1}

\begin{tabular}{|c|c|c|c|c|c|c|c|c|}
\hline \multicolumn{9}{|c|}{ Coefficients $^{a}$} \\
\hline \multirow[b]{2}{*}{ Model } & & \multicolumn{2}{|c|}{$\begin{array}{l}\text { Unstandardized } \\
\text { Coefficients }\end{array}$} & $\begin{array}{l}\text { Stan } \\
\text { ized } \\
\text { Coef } \\
\text { nts }\end{array}$ & & & \multicolumn{2}{|c|}{$\begin{array}{l}\text { Collinearity } \\
\text { Statistics } \\
\text { Toleran }\end{array}$} \\
\hline & & $\mathrm{B}$ & Std. Error & Beta & $\mathrm{t}$ & Sig. & ce & VIF \\
\hline \multirow[t]{2}{*}{1} & (Constant) & 14.533 & 4.094 & & 3.549 & .001 & & \\
\hline & ISO & .226 & .056 & .403 & 4.012 & .000 & 1.000 & 1.000 \\
\hline
\end{tabular}

a. Dependent Variable: KM

Sumber : Data Primer yang diolah

Hipotesis kedua menguji partisipasi penyusunan anggaran $\left(\mathrm{X}_{2}\right)$ berpengaruh secara signifikan terhadap dan kinerja manajerial (Y). Pengujian ini dilakukan dengan menggunakan regresi linear sederhana melalui uji koefisien determinasi dan uji statistik t. Pada tabel 5 dan 6 dapat dilihat hasil uji koefisien determinasi dan uji statistik $t$ hipotesis 2 , sebagai berikut:

Tabel 5. Hasil Uji Koefisien Determinasi Hipotesis 2

Model Summaryb

\begin{tabular}{|c|c|c|c|c|c|}
\hline Model & $\mathrm{R}$ & R Square & $\begin{array}{l}\text { Adjusted R } \\
\text { Square }\end{array}$ & $\begin{array}{l}\text { Std. Error of } \\
\text { the Estimate }\end{array}$ & $\begin{array}{l}\text { Durbin- } \\
\text { Watson }\end{array}$ \\
\hline 1 & $.485^{\mathrm{a}}$ & .236 & .226 & 4.994 & 1.847 \\
\hline
\end{tabular}

a. Predictors: (Constant), PA

b. Dependent Variable: KM

Sumber: Data primer yang diolah

Hasil perhitungan nilai R berdasarkan tabel 5 diatas diperoleh angka korelasi 0,485 artinya hubungan variabel dependen dan independen adalah 
sedang. Korelasi positif menunjukkan hubungan yang searah, artinya semakin meningkatkan partisipasi penyusunan anggaran maka kinerja manajerial akan meningkat. Berdasarkan nilai $\mathrm{R}$ Square $\left(\mathrm{R}^{2}\right)$ tabel 5 menunjukan variabel partisipasi penyusunan anggaran dapat menjelaskan 23,6 \% variabel kinerja manjerial. Sisanya 76,4 dijelaskan oleh sebab-sebab lain diluar model. Berikut ini disajikan hasil uji statistik t hipotesis 2 pada Tabel 6;

Tabel 6. Hasil Uji Statistik t Hipotesis 2

\begin{tabular}{|c|c|c|c|c|c|c|c|}
\hline \multicolumn{8}{|c|}{ Coefficients $^{a}$} \\
\hline \multirow[b]{5}{*}{ Model } & \multirow{3}{*}{\multicolumn{2}{|c|}{$\begin{array}{l}\text { Unstandardized } \\
\text { Coefficients }\end{array}$}} & $\begin{array}{l}\text { Stanc } \\
\text { zed }\end{array}$ & & & \multirow{4}{*}{\multicolumn{2}{|c|}{$\begin{array}{l}\text { Collinearity } \\
\text { Statistics } \\
\text { Tolera }\end{array}$}} \\
\hline & & & Coeff & & & & \\
\hline & & & nts & & & & \\
\hline & & Std. & & & & & \\
\hline & $\mathrm{B}$ & Error & Beta & $\mathrm{t}$ & Sig. & nce & VIF \\
\hline 1 (Constant) & 20.273 & 2.151 & & 9.425 & .000 & & \\
\hline $\mathrm{PA}$ & .542 & .107 & .485 & 5.057 & .000 & 1.00 & 1.000 \\
\hline
\end{tabular}

a. Dependent Variable: KM

Sumber: data primer yang diolah

Berdasarkan Tabel 6 diperoleh hasil nilai $\mathrm{t}$ hitung pada variabel partisipasi penyusunan anggaran sebesar 5,057 pada tingkat siginifikan 0,000 yang berarti lebih kecil dari 0,05, sehingga uji t dapat simpulkan bahwa secara individual pertisipasi penyusunan anggaran mempunyai pengaruh yang signifikan terhadap variabel kinerja manajerial. Hal ini berarti mendukung $\mathrm{H}_{2}$ yang menyatakan bahwa partisipasi penyusunan anggaran berpengaruh secara signifikan terhadap kinerja manajerial. Hasil penelitian ini konsisten dengan penelitian yang dilakukan oleh Sumarno (2005) dan Noor (2009) yang menyatakan bahwa partisipasi penyusunan anggaran berpengaruh secara siginifikan dengan kinerja manajerial.

Hipotesis ketiga menguji sistem manajemen mutu ISO 9001: 2008 (X $\left.\mathrm{X}_{1}\right)$ dan partisipasi penyusunan anggaran $\left(\mathrm{X}_{2}\right)$ berpengaruh secara signifikan terhadap dan kinerja manajerial (Y). Pengujian hipotesis ketiga dilakukan dengan menggunakan regresi linear berganda melalui uji koefisien determinasi, Uji statisti F (Anova) dan uji statistik t. Pada tabel 7, 8 dan 9 dapat dilihat hasil 
uji koefisien determinasi, Uji Statistik F (Anova) dan uji statistik t hipotesis 3, sebagai berikut :

Tabel 7. Hasil Uji Koefisien Determinasi Hipotesis 3

Model Summaryb

\begin{tabular}{rrrrrrr}
\hline Model & $\mathrm{R}$ & R Square & R Square & Edjusted & $\begin{array}{r}\text { Std. Error of the } \\
\text { Estimate }\end{array}$ & $\begin{array}{r}\text { Durbin- } \\
\text { Watson }\end{array}$ \\
\hline 1 & $.548^{\mathrm{a}}$ & .300 & .283 & 4.808 & 1.745
\end{tabular}

a. Predictors: (Constant), PA, ISO

b. Dependent Variable: KM

Sumber : data primer yang diolah

Hasil perhitungan nilai $\mathrm{R}$ berdasarkan Tabel 7 diatas diperoleh angka korelasi 0,548 artinya hubungan variabel dependen dan independen adalah sedang. Korelasi positif menunjukan hubungan yang searah, artinya semakin meningkatkan sistem manajemen mutu ISO 9001:2008 dan partisipasi penyusunan anggaran gaya, maka kinerja manajerial akan meningkat. Berdasarkan nilai Adjusted $\mathrm{R}$ Square (Adjusted $\mathrm{R}^{2}$ ) Tabel 7 menunjukan variabel sistem manajemen mutu ISO 9001:2008 dan partisipasi penyusunan anggaran menjelaskan 28,3\% variabel kinerja manjerial. Sisanya 71,7 \% dijelaskan oleh sebab-sebab lain diluar model.

\section{Tabel 8. Hasil Uji Statistik F Hipotesis 3}

\begin{tabular}{|c|c|c|c|c|c|c|}
\hline \multicolumn{7}{|c|}{ ANOVA $^{b}$} \\
\hline Model & & $\begin{array}{l}\text { Sum of } \\
\text { Squares }\end{array}$ & $\mathrm{df}$ & Mean Square & $\mathrm{F}$ & Sig. \\
\hline \multirow[t]{3}{*}{1} & Regression & 811.846 & 2 & 405.923 & 17.558 & $.000^{\mathrm{a}}$ \\
\hline & Residual & 1895.754 & 82 & 23.119 & & \\
\hline & Total & 2707.600 & 84 & & & \\
\hline
\end{tabular}

a. Predictors: (Constant), PA, ISO

b. Dependent Variable: KM

Sumber : Data Primer yang diolah 
Hasil Uji F yang ditunjukan dalam tabel 8 menjelaskan bahwa nilai significance (probabilita) 0,000 lebih kecil dari 0,05, hal ini mengindikasikan bahwa Hipotesis 3 diterima, yang berarti bahwa hipotesis yang menyatakan bahwa sisitem manajemen mutu ISO 9001:2008 dan partisipasi penyusunan anggaran secara simultan dan signifikan dapat berpengaruh terhadap kinerja manajerial dapat dibuktikan secara nyata.

Berikut ini disajikan hasil uji statistik t hipotesis 3 pada tabel 9

\section{Tabel 9. Hasil Uji Statistik t Hipotesis 3}

\section{Coefficients $^{\mathrm{a}}$}

\begin{tabular}{|c|c|c|c|c|c|c|c|c|}
\hline \multirow{2}{*}{\multicolumn{2}{|c|}{ Model }} & \multicolumn{2}{|c|}{$\begin{array}{c}\text { Unstandardized } \\
\text { Coefficients }\end{array}$} & \multirow{2}{*}{$\begin{array}{c}\text { Standardi } \\
\text { zed } \\
\text { Coefficien } \\
\text { ts } \\
\text { Beta }\end{array}$} & \multirow[b]{2}{*}{$\mathrm{t}$} & \multirow[b]{2}{*}{ Sig. } & \multicolumn{2}{|c|}{$\begin{array}{c}\text { Collinearity } \\
\text { Statistics }\end{array}$} \\
\hline & & B & $\begin{array}{l}\text { Std. } \\
\text { Error }\end{array}$ & & & & $\begin{array}{l}\text { Toler } \\
\text { ance }\end{array}$ & VIF \\
\hline & (Constant) & 11.374 & 3.848 & & 2.956 & .004 & & \\
\hline & ISO & .151 & .055 & .270 & 2.744 & .007 & .885 & 1.130 \\
\hline & PA & .440 & .110 & .394 & 4.012 & .000 & .885 & 1.130 \\
\hline
\end{tabular}

a. Dependent Variable: KM

Sumber : data primer yang diolah

Berdasarkan tabel 9 diperoleh hasil nilai t hitung pada variabel sistem manajemen mutu ISO 9001:2008 sebesar 2,744 pada tingkat siginifikan 0,007 yang berarti lebih kecil dari 0,05, sehingga uji t dapat simpulkan bahwa secara individual sistem manajemen mutu ISO 9001:2008 mempunyai pengaruh yang signifikan terhadap variabel kinerja manajerial. Nilai t hitung atas variabel partisipasi penyusunan anggaran sebesar 4,012 pada tingkat siginifikansi 0,000 yang berarti signifikan, karena lebih kecil dari 0,05. Sehingga dari hasil uji t dapat disimpulkan partisipasi penyusunan anggaran mempunyai pengaruh siginifikan terhadap kinerja manajerial.

Hasil penelitian ini mendukung Hipotesis $\left(\mathrm{H}_{3}\right)$ yang menyatakan sisitem manajemen mutu ISO 9001:2008 dan partisipasi penyusunan anggaran berpengaruh secara signifikan terhadap kinerja manajerial. Hal ini berarti 
secara individual variabel sistem manajemen mutu ISO 9001:2008 dan partisipasi penyusunan anggaran terhadap kinerja manajerial merupakan kombinasi dua variabel independen yang dapat meningkatkan kinerja manajerial. Hasil penelitian ini konsisten dengan teori yang di kembangkan oleh Van den Berghe (1997), beliau menyebutkan salah satu motif utama yang dimiliki oleh perguruan tinggi untuk menerapkan ISO 9001:2008 yaitu untuk mengembangkan sistem manajmen mutu secara keseluruhan dan untuk mendorong peningkatan secara spesifik pada beberapa kegiatan organisasi atau manajerial.

\section{SIMPULAN}

Penelitian ini mendukung hipotesis pertama $\left(\mathrm{H}_{1}\right)$ yang menyatakan bahwa sistem manajemen mutu ISO 9001:2008 berpengaruh secara siginifikan terhadap kinerja manajerial. Semakin baik tingkat pemahaman dan kesadaran dalam penerapan sistem manajemen mutu ISO 9001:2008 yang dilakukan oleh setiap seorang pimpinan, dosen dan karyawan UIN Syarif Hidayatullah Jakarta, maka semakin baik pula kinerja dari para pimpinan, dosen dan karyawan tersebut.

Penelitian ini mendukung hipotesis kedua $\left(\mathrm{H}_{2}\right)$ yang menyatakan bahwa partisipasi penyusunan anggaran berpengaruh secara siginifikan terhadap kinerja manajerial. Semakin tinggi tingkat partisipasi seorang pimpinan UIN Syarif Hidayatullah Jakarta pada saat penyusunan anggaran, maka semakin tinggi pula kinerja dari pimpinan, dosen dan karyawan tersebut.

Penelitian ini mendukung hipotesis ketiga $\left(\mathrm{H}_{3}\right)$ yang menyatakan bahwa sistem manajemen mutu ISO 9001:2008 dan partisipasi penyusunan anggaran berpengaruh secara simultan dan siginifikan terhadap kinerja manajerial. Semakin baik tingkat pemahaman dan kesadaran dalam penerapan sistem manajemen mutu ISO 9001:2008, ditambah dengan semakin tinggi tingkat partisipasi anggaran yang dilakukan oleh para pimpinan, dosen dan karyawan UIN Syarif Hidayatullah Jakarta, maka secara bersamaan kedua 
variabel tersebut dapat mempengaruhi dalam peningkatan kinerja manajerial.

\section{PUSTAKA ACUAN}

Adrianto, Y. 2008. Analisis Pengaruh Penyusunan Anggaran Terhadap Kinerja Manajerial dengan Kepuasan Kerja, Job Relevant Informasion, Motivasi kerja Sebagai Variabel Moderating. (Tesis Tidak Dipublikasikan) Semarang: Universitas Diponegoro.

Ahmad, K. 2005. Akuntansi Manajemen: Dasar-dasar konsep biaya dan pengambilan keputusan. Jakarta: PT. Raja Grafindo Persada.

Allen \& Meyer. 1990. The measurement and antecedents of affective, continuance and normative commitment to the organization. Journal of Occupational Psychology, 63, pp. 1-18.

Anthony, R, N. \& V. Govindarajan. 2005. Sistem Pengendalian Manajemen. Edisi 2 Buku 2. Jakarta: Salemba Empat

Arifah, J. 2009. Kontribusi Partisipasi Anggaran, Komitmen Organisasi Dengan Sejangan Anggaran Serta Dampaknya terhadap Kinerja Aparat Pemerintah. Jurnal Akuntabilitas, Vol 2. No. 1 No.1 Hlm 72 - 87.

Bayangkara, IBK. 2010. Audit Manajemen: Prosedur dan Implementasinya. Jakarta: Salemba Empat

Brownell, P. 1982. The Role Of Accounting Data in Performance Evaluation, Budgetary Participation, and Organizational Effectiveness. Journal of Accounting Resarch, Vol. 20 No. 1, pp 12-27

Carter, W. \& K. Usry. 2009. Cost Accounting. Jakarta: Salemba Empat..

Fitrianti, N. 2010. Pengaruh partisipasi Anggaran terhadap Kinerja Manajerial Dengan Gaya Kepemimpinan Dan Iklim Organisasi Sebagai Variabel Moderating. (Skripsi Tidak Dipublikasikan). Jakarta: UIN Syarif Hidayatullah Jakarta.

Gaspersz, V. 2001. Metode Analisis untuk peningkatan Kualitas. Jakarta: Gramedia Pusataka Utama. 
Gaspersz, V. 2002. Manajemen Bisnis Total Dalam Era Globalisasi. Jakarta: Gramedia Pustaka Utama.

Ghozali, I. 2005. Aplikasi Analisis Multivariate dengan Program SPSS. Semarang: Badan Penerbit Universitas Diponegoro.

Halim, A, dkk. 2000. Sistem Pengendalian Manajemen. Yogyakarta: UPP AMP YKPN.

Hansen, D.R \& M.M. Mowen. 2009. Managerial Accounting, Buku 1 Edisi 8. Jakarta: Salemba Empat.

International Organizatioan For Standardization. 2012. Sistem Manajemen Mutu Persyaratan (ISO 9001:2008, IDT). Jakarta: Badan Standarisasi Nasional. 2

International Organization for Standarization" About ISO. (on-line) http:WW.ISO.Org/about/htm (diakses tanggal 15 Maret 2014): 2014.

Lestari, I. 2012. Pengaruh Sistem Penjaminan Mutu Internal dan Sistem Manajemen Mutu ISO 9001:2008 terhadap Kinerja Universitas Katolik Indonesia Atmajaya Jakarta. (Tesis Tidak Dipublikasikan). Jakarta: Universitas Indonesia.

Lupia, A. \& M. McCubbins. 2000. Representation or abdication? How citizens use institutions to help delegation succeed. European Journal of Political Research 37: pp. 291-307.

Mardiasmo. 2002. Akuntansi Sektor Publik. Yogyakarta: Andi Offiset.

Milani, K. 1975. The Relationship of Participan in Budget Setting to Industrial Supervisor Perfomance and Attitude : A Field Study. The Accounting Riview, Vol 10 No. 2 April, pp 274284.

Nor, W. 2009. Desentralisasi dan Gaya Kepemimpinan sebagai variabel Moderating dalam Hubungan anatara Partisipasi Anggaran dan Kinerja Manajerial. Jurnal Media Bisnis dan Manajemen Volume 9 Nomor 3, hlm. 217-239.

Nurcahyani, K. 2010. Pengaruh Partisipasi Anggaran terhadap kinerja Manajerial Melalui Komitmen Organisasi dan Persepsi Inovasi Sebagai Variabel 
Intervening. (Skripsi Tidak Dipublikasikan). Semarang: Universitas Dipenogoro.

Othman, R, et.al. 2007. ISO Standard Implementation at Private Colleged: Academics and Non Academics Perspective. The $1^{\text {st }}$ International Conference on Educational Reform, November 9-11, Mahasarakham University, Thailand.

Peraturan Pemerintah Republik Indonesia Nomor 23 tahun 2005 tentang Pola Keuangan Badan Layanan Umum. Jakarta

Priyatno, D. 2008. Mandiri Belajar SPSS. Yogyakarta: Mediakom.

Santoso, S. 2004. Buku Latihan SPSS Statistik Parametrik. Jakarta: PT. Elex Media Komputindo.

Sardjito, B. \& O. Muthaher. 2007. Pengaruh Partisipasi Penyusunan Anggaran Terhadap Kinerja Aparat Pemerintah Daerah: Buadaya Organisasi sebagai variabel moderating. Simposium Nasional Akuntansi X, Makasar, 26 -28 Juli 2007.

Sugiyono. 2009. Metodologi Penelitian Bisnis, Edisi13. Bandung: Penerbit CV. Alfabeta.

Sumarno, J. 2005. Pengaruh Komitmen Organisasi dan Gaya Kepemimpinan terhadap Hubungan antara partisipasi dalam penyusunan Anggaran dengan Kinerja Manajerial. Simposium Nasional Akuntansi VIII, Solo, 15-16 September 2005.

TIM LPJM Fakultas Ekonomi dan Bisnis UIN Syarif Hidayatullah Jakarta. 2012. Pedoman Mutu Sistem Manajemen Mutu ISO 9001:2008. tahun 2012

Welsch, G.A. dkk. 2000. Budget: Planing and Profit Control. Jakarta: Salemba Empat.

Yuniarti, dkk. 2007. Komitmen Organisasi dan Gaya Kepemimpinan dalam Hubungan antara Partisipasi Anggaran dan Kinerja Manajerial. (Laporan penelitian). Lampung: Politeknik Negeri Lampung. 
Yusfaningrum, K. \& I. Ghozali. 2005. Analisis Pengaruh Partisipasi Anggaran Terhadap Kinerja Manajerial Melalui Komitmen Tujuan Anggaran dan Job Relevant Informasi (JRI) sebagai variable Intervening Simposium Nasional Akuntansi VIII, Solo, 15-16 September 2005. 